\title{
1 Molecular Epidemiology of SARS-CoV-2 in Cyprus
}

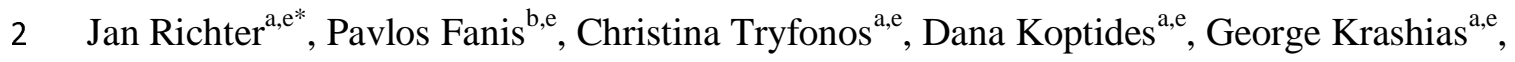

3 Stavros Bashiardes ${ }^{\mathrm{a}, \mathrm{e}}$, Andreas Hadjisavvas $^{\mathrm{c}, \mathrm{e}}$, Maria Loizidou $^{\mathrm{c}, \mathrm{e}}$, , Anastasis Oulas ${ }^{\mathrm{d}, \mathrm{e}}$, Denise

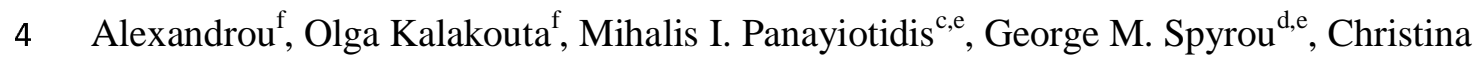

5 Christodoulou ${ }^{\mathrm{a}, \mathrm{e}}$

7 Affiliations:

$8{ }^{a}$ Molecular Virology Department, Cyprus Institute of Neurology and Genetics, Nicosia,

9 Cyprus

$10{ }^{\mathrm{b}}$ Molecular Genetics, Function \& Therapy Department, Cyprus Institute of Neurology and

11 Genetics, Nicosia, Cyprus

$12{ }^{\mathrm{c} C a n c e r}$ Genetics, Therapeutics \& Ultrastructural Pathology Department, Cyprus Institute of

13 Neurology and Genetics, Nicosia, Cyprus

$14{ }^{\mathrm{d}}$ Bioinformatics Department, Cyprus Institute of Neurology and Genetics, Nicosia, Cyprus

$15{ }^{\mathrm{e}}$ The Cyprus School of Molecular Medicine, Cyprus Institute of Neurology and Genetics,

16 Nicosia, Cyprus

$17{ }^{\mathrm{f}}$ Medical and Public Health Services, Ministry of Health, Nicosia, Cyprus

$19 *$ Corresponding author

20 e-mail: richter@cing.ac.cy

22 Keywords: SARS-CoV-2, COVID-19, whole genome sequencing, epidemiology, Cyprus 
medRxiv preprint doi: https://doi.org/10.1101/2021.03.16.21252974; this version posted March 24, 2021. The copyright holder for this preprint (which was not certified by peer review) is the author/funder, who has granted medRxiv a license to display the preprint in perpetuity.

It is made available under a CC-BY-NC-ND 4.0 International license .

\section{Abstract}

24 Whole genome sequencing of viral specimens following molecular diagnosis is a powerful 25 analytical tool of molecular epidemiology that can critically assist in resolving chains of 26 transmission, identifying of new variants or assessing pathogen evolution and allows a real27 time view into the dynamics of a pandemic. In Cyprus, the first two cases of COVID-19 were 28 identified on March 9, 2020 and since then 33,567 confirmed cases and 230 deaths were 29 documented. In this study, viral whole genome sequencing was performed on 133 SARS-

30 CoV-2 positive samples collected between March 2020 and January 2021. Phylogenetic 31 analysis was conducted to evaluate the genomic diversity of circulating SARS-CoV-2 32 lineages in Cyprus. 15 different lineages were identified that clustered into three groups 33 associated with the spring, summer and autumn/winter wave of SARS-CoV2 incidence in 34 Cyprus, respectively. The majority of the Cypriot samples belonged to the B.1.258 lineage 35 first detected in September that spread rapidly and largely dominated the autumn/winter wave 36 with a peak prevalence of $86 \%$ during the months of November and December. The B.1.1.7

37 UK variant (VOC-202012/01) was identified for the first time at the end of December and 38 spread rapidly reaching $37 \%$ prevalence within one month. Overall, we describe the changing 39 pattern of circulating SARS-CoV-2 lineages in Cyprus since the beginning of the pandemic 40 until the end of January 2021. These findings highlight the role of importation of new 41 variants through travel towards the emergence of successive waves of incidence in Cyprus 42 and demonstrate the importance of genomic surveillance in determining viral genetic 43 diversity and the timely identification of new variants for guiding public health intervention 44 measures. 
medRxiv preprint doi: https://doi.org/10.1101/2021.03.16.21252974; this version posted March 24, 2021. The copyright holder for this preprint (which was not certified by peer review) is the author/funder, who has granted medRxiv a license to display the preprint in perpetuity.

It is made available under a CC-BY-NC-ND 4.0 International license .

\section{Introduction}

47 Corona Virus Disease-2019 (COVID-19) is a pulmonary disease caused by the Severe Acute

48 Respiratory Syndrome Coronavirus 2 (SARS-CoV-2) coronavirus [1]. SARS-CoV-2 was first

49 detected in December 2019 in Wuhan city in the Hubei province of China in a patient with

50 acute pneumonia [2,3]. Following global spread of the virus, on March 11, 2020 the World

51 Health Organization (WHO) characterized COVID-19 as a pandemic, which is still ongoing

52 and as of February 24, 2021 over 110 million confirmed cases and 2.47 million deaths were

53 reported worldwide (https://covid19.who.int/).

54 The complete genome of SARS-CoV-2 isolated from a patient in Wuhan, China was initial

55 published on Jan 5, 2020 [2] and since then analysis of viral sequences worldwide is

56 continuous with more than 614,000 complete genomes currently available in public databases

57 such as the GISAID (https ://www.gisaid.org/). The global real-time tracing of the viral

58 spread through whole genome sequencing is important in the race to timely identify the

59 emergence of novel SARS-CoV-2 variants that change the transmission, antigenic properties

60 and/or pathogenicity of the virus [4]. The recent identification of three major Variants of

61 Concern (VOC), with increased transmissibility and the potential to reduce vaccine

62 effectiveness has led to increased surveillance efforts worldwide $[5,6]$.

63 The Republic of Cyprus is one of the countries in Europe least affected by the COVID-19

64 pandemic, presumably due to its rapid and effective response strategy that included high

65 number of COVID-19 tests, effective tracing and isolation of cases and their contacts together

66 with preventive measures (e.g. social distancing, wearing face masks and hand washing) [7].

67 In addition, being an island guaranteed high effectiveness of airport closure with regard to

68 importing of new cases. The first two cases of COVID-19 in Cyprus were identified on

69 March 9, 2020 and since then 33,567 confirmed cases and 230 deaths were documented

70 (https://covid19.ucy.ac.cy/). 
medRxiv preprint doi: https://doi.org/10.1101/2021.03.16.21252974; this version posted March 24, 2021. The copyright holder for this preprint (which was not certified by peer review) is the author/funder, who has granted medRxiv a license to display the preprint in perpetuity.

It is made available under a CC-BY-NC-ND 4.0 International license .

71 The aim of our study was to analyse and evaluate the genomic diversity of circulating SARS-

72 CoV-2 lineages in Cyprus. We report 133 full genome sequences obtained from individuals

73 tested positive by RT-PCR between March 2020 and January 2021 and evaluate their

74 characteristics and relationship with the progression of the pandemic in Cyprus. Public

75 sharing and use of genomic analyses are important tools for disease surveillance systems to

76 track and trace acquired COVID-19 cases for more accurate decision making and appropriate

77 public health action.

79 Materials and Methods

80 Sample collection

81 The Department of Molecular Virology of Cyprus Institute of Neurology and Genetics was

82 assigned as the reference laboratory for SARS-CoV2 by the Cyprus Ministry of Health of the

83 Republic of Cyprus. More than 180,000 samples from public as well as private hospitals were

84 received and analysed since March 2020. For this retrospective observational study 133

85 SARS-CoV2 positive nasopharyngeal swabs obtained from patients referred for diagnostic

86 purposes between March 2020 and January 2021 were selected for full genome sequencing.

87 A random, unselected approach for sample selection was taken without pre-screening for

88 variants of interest to avoid sampling bias. The viral RNA had been previously detected using

89 a qRT-PCR assay and all samples selected had a cycle threshold value (Ct) lower than 30.

90 The study was approved by the Cyprus National Bioethics committee (EEBK 21.1.01.03). 
medRxiv preprint doi: https://doi.org/10.1101/2021.03.16.21252974; this version posted March 24, 2021. The copyright holder for this preprint (which was not certified by peer review) is the author/funder, who has granted medRxiv a license to display the preprint in perpetuity.

It is made available under a CC-BY-NC-ND 4.0 International license .

\section{$92 \quad$ Next Generation Sequencing}

93 Total RNA was extracted from $200 \mu$ of nasopharyngeal swab fluid in a final volume of 50

$94 \mu$ l, using the MagMAX Viral/Pathogen Nucleic Acid Isolation Kit (Applied Biosystems) on a

95 KingFisher ${ }^{\mathrm{TM}}$ Flex Purification System (Thermo Fisher Scientific). Libraries were prepared 96 using the QIAseq SARS-CoV-2 Primer Panel in conjunction with the QIAseq FX DNA 97 Library Kit (Qiagen) according to manufacturer's instructions. In brief, viral RNA was 98 reverse transcribed to synthesize cDNA using random hexamers. cDNAs were amplified in 99 two high-fidelity multiplex PCR reactions using two different primer pools that together 100 cover the entire SARS-CoV2 genome. The two enriched pools per sample were combined, 101 purified using AMPure XP beads (Beckman Coulter) and quantified using the Qubit dsDNA 102 HS Assay kit (Invitrogen). Fragmentation, end-repair and A-tailing was performed in a 103 combined reaction per sample using 200 ng DNA. Next, Illumina platform-specific adapters 104 were ligated to both ends of the DNA fragments. Library size selection and purification were 105 carried out using AMPure XP beads (Beckman Coulter) in two rounds $(0.8 \mathrm{x}$ and $1 \mathrm{x}$ respectively). The libraries were quality analyzed using the Agilent High Sensitivity D1000 ScreenTape on a 2200 TapeStation system (Agilent) and quantified using the Qubit dsDNA HS Assay kit (Invitrogen). Equimolar quantities of libraries were pooled (24 samples/pool) and sequenced on a Illumina MiSeq sequencer. All sequences obtained were deposited at the GISAID EpiCov database (www.gisaid.org).

\section{Mapping, alignment and lineage assignment}

112 The Burrows-Wheeler Aligner (BWA), version: 0.7 .15 was used to map the raw reads to the 113 coronavirus reference genome Wuhan-Hu-1 (NCBI ID:NC_045512.2) [8]. Duplicate reads, 114 which are likely to be the results of PCR bias, were marked using Picard version: 2.6.0 
medRxiv preprint doi: https://doi.org/10.1101/2021.03.16.21252974; this version posted March 24, 2021. The copyright holder for this preprint (which was not certified by peer review) is the author/funder, who has granted medRxiv a license to display the preprint in perpetuity.

It is made available under a CC-BY-NC-ND 4.0 International license .

116 BAM/SAM file manipulations [9]. SNPs, amino acid replacements and indels were verified

117 using the CoV-Glue web interface [10]. Aligned reads were validated using the Integrative

118 Genomics Viewers v.2.9.2 and consensus sequences were extracted [11]. SARS-CoV2

119 lineages of the 133 sequences were assigned using the dynamic nomenclature tool

120 PANGOLIN (https://pangolin.cog-uk.io) [12].

\section{Phylogenetic analysis}

122 All phylogenetic analyses were conducted in MEGA7 [13]. The alignment of consensus

123 sequences was performed using MUSCLE. Bayesian information criterion (BIC) scores were

124 calculated for different models to determine the best fitting nucleotide substitution model. In

125 addition, jModelTest [14] was used for evaluating the best fitting nucleotide substitution

126 model under BIC yielding the same result (TN93model + gamma distributed rates). This

127 model was subsequently used to construct a Maximum Likelihood phylogenetic tree with

1281000 bootstrap replicates. All positions containing alignment gaps and missing data were

129 eliminated only in pairwise sequence comparisons.

131 Results and Discussion

132 Since the beginning of the pandemic and until the 24/2/2021, the Republic of Cyprus reported

13333,567 SARS-CoV2 confirmed cases (3.63\% of the population) along with 230 associated

134 casualties (24.2/100,000) (https://covid19.ucy.ac.cy/). Based on the number of positives

135 identified (see Fig 1) the course of the pandemic in Cyprus so far can be distinguished into

136 three main phases: a first phase during Spring 2020, starting with the first two cases identified

137 on the $9^{\text {th }}$ of March that peaked in the first week of April that was contained with a

138 nationwide lock-down and lasted approximately until June; a second phase during the

139 summer that started after the re-opening of the airports; and a third phase (which is still 
medRxiv preprint doi: https://doi.org/10.1101/2021.03.16.21252974; this version posted March 24, 2021. The copyright holder for this preprint (which was not certified by peer review) is the author/funder, who has granted medRxiv a license to display the preprint in perpetuity.

It is made available under a CC-BY-NC-ND 4.0 International license .

continuing) during autumn/winter that peaked at the beginning of January and accounted for the majority of all cases registered so far.

Overall, between the $11^{\text {th }}$ of March 2020 and the $29^{\text {th }}$ of January 2021, 15 different lineages were identified among the 133 samples sequenced (Table 1). As shown in Fig 3 the phylogenetic analysis is in support of the PANGOLIN lineages assignment and reveals a picture of independent distinct, importations that are followed by local transmission (Fig 3). In the bubble chart in Fig 2 three groups of lineages are clearly distinguishable and associate with the three phases of the SARS-CoV2 pandemic.

During the spring wave four variants (B.1.1.74, B.1.1.277, B.1.235 and B.1.1.251) were identified reflecting several independent importation events followed by local transmission. However, concomitant with the decline in reported positive cases following the country-wide lockdown, by the end of June these SARS-CoV-2 variants were no longer detected and none of these re-emerged during the second or the third wave.

Following the re-opening of the airports, the summer months of July and August were characterized by multiple distinct introductions of a variety of new lineages (B.1.36, B.1.236, B.1.2, B.1.1.67, B.1.1.288, B.1.1.192), which marked the beginning of a small second wave (Fig 3). The majority of the samples belonged to lineage B.1.2 and B1.236 accounting for $86 \%$ of the samples in that wave, however, all these lineages again subsequently vanished. The B.1.2 lineage has been otherwise observed only infrequently in Europe, but has been very common in the United States and in Canada [15].

In September, two new lineages were identified for the first time, which were set to dominate the autumn/winter wave until December, namely the B.1.177 and the B.1.258 variants.

The B.1.177 lineage, which is characterized by the A222V spike mutation, was previously been shown to have emerged in Spain in early summer and subsequently became widespread 
medRxiv preprint doi: https://doi.org/10.1101/2021.03.16.21252974; this version posted March 24, 2021. The copyright holder for this preprint (which was not certified by peer review) is the author/funder, who has granted medRxiv a license to display the preprint in perpetuity.

It is made available under a CC-BY-NC-ND 4.0 International license .

across Europe as well as Canada, accounting for the majority of sequences by autumn 2020 $[16,17]$. However, no evidence of increased transmissibility of this variant was reported [18]. In Cyprus, this lineage was first identified on the $19^{\text {th }}$ of September and continued to circulate until the end of January at a relatively low but constant frequency fluctuating between $4 \%$ and $15 \%$.

In September, the B.1.258 lineage was introduced, which spread rapidly and largely dominated the autumn/winter wave with a peak prevalence of $86 \%$ during the months of November and December.

All samples belonging to the B.1.258 variant identified in Cyprus contain the six-nucleotide $\Delta \mathrm{H69} / \mathrm{V} 70$ deletion in the $\mathrm{S}$ gene, which was recently proposed to be labelled B.1.258 $[19]$.

This deletion, which has been shown to enhance viral infectivity [20] has arisen at least six times independently and frequently followed receptor binding AA replacements (i.e. N501Y, $\mathrm{N} 439 \mathrm{~K}, \mathrm{Y} 453 \mathrm{~F})$ ([19]). In addition, the B.1.258 variant is characterised by the N439K mutation that confers an increased binding affinity to the hACE2 receptor and leads simultaneously to immune escape from a panel of neutralizing monoclonal antibodies as well as from sera of persons recovered from infection [21].

By the end of December, the B.1.1.7 UK variant, also known as 20I/501Y.V1 and Variant of Concern 202012/01 (VOC-202012/01), was identified for the first time in the Cypriot sample set. This lineage was first reported on the $20^{\text {th }}$ December in the United Kingdom and drew immediate attention due to its rapid spread and increased transmissibility [22]. The earliest sampled genome of the B.1.1.7 variant dates back to the $20^{\text {th }}$ of September. Since then it has grown rapidly in frequency in the UK becoming the most prevalent lineage there with a similar development also observed in a variety of other European countries, including Ireland, Spain and Greece [23]. It is characterised by an unusual large number of genetic 
medRxiv preprint doi: https://doi.org/10.1101/2021.03.16.21252974; this version posted March 24, 2021. The copyright holder for this preprint (which was not certified by peer review) is the author/funder, who has granted medRxiv a license to display the preprint in perpetuity.

It is made available under a CC-BY-NC-ND 4.0 International license .

changes including the receptor-binding domain and it is speculated that it may have originated in a chronically infected immunocompromised person. In our sample set the frequency of this variant increased in a similar rapid manner from $3.4 \%$ in December to $38 \%$ by the end of January despite declining case numbers highlighting its superior fitness.

\section{Conclusions}

Whole genome sequencing of viral specimens following molecular diagnosis is a powerful analytical tool of molecular epidemiology that can critically assist in resolving chains of transmission, identifying of new variants or assessing pathogen evolution and allows a realtime view into the dynamics of a pandemic [24]. In this study we describe for the first time the changing pattern of circulating SARS-CoV-2 lineages in Cyprus since its appearance between March 2020 and the end of January 2021. Distinct lineages of SARS-CoV-2 contributing to three separate waves of infections reflective of the epidemiological pattern were observed.

The global real-time tracing of the viral spread through whole genome sequencing has led recently to the identification of three major Variants of Concern (VOC). Lineage B.1.1.7 (20I/501Y.V1, VOC-202012/01) better known as the UK variant possesses an unusual high number of mutations is believed to be more transmissible than the wild-type virus. Lineage B.1.351 (501.V2, 20H/501Y.V2, VOC-202012/02) first detected and reported in South Africa in early October 2020, shares several mutations with B.1.1.7 and is feared to reduce to some extend vaccine effectiveness [25]. In Brazil, the P.1 (20J/501Y.V3, VOC-202101/02) lineage emerged in December 2020 [26]. The P.1 lineage contains ten mutations in the spike protein that may affect its ability to be recognized by antibodies $[27,28]$. 
medRxiv preprint doi: https://doi.org/10.1101/2021.03.16.21252974; this version posted March 24, 2021. The copyright holder for this preprint (which was not certified by peer review) is the author/funder, who has granted medRxiv a license to display the preprint in perpetuity.

It is made available under a CC-BY-NC-ND 4.0 International license .

211 Of these three VOC only the B1.1.7 variant has so far been identified in Cyprus, which after

212 being encountered for the first time at the end of December was able to reach $37 \%$ prevalence

213 within one month. The majority of the Cypriot samples analysed belonged to the B.1.258

214 lineage, which has been first detected at the beginning of August in Switzerland and has since

215 then spread to numerous European countries where it became one of the most prevalent

216 lineages by December including the Czech Republic, Slovakia and Sweden [19,29]. The

217 N439K receptor binding motif characteristic of this lineage has previously been reported to

218 confer an increased binding affinity to the hACE2 receptor and simultaneously leading to

219 immune escape from a panel of neutralizing monoclonal antibodies as well as from sera of

220 persons recovered from infection [21]. The association of mutations found in the B.1.258

221 lineage with increased fitness and immune evasion along with the high prevalence in several

222 European countries stipulates further characterisation of this variant. A continuous

223 surveillance of SARS-CoV2 by whole genome sequencing continues to be critical for timely

224 detection of emerging variants, identifying transmission modes and guiding public health

225 intervention.

227 Declaration of conflicting interest

228 All authors declare that there is no conflict of interest.

\section{$230 \quad$ Funding}

231 The study was supported by seed funding from The Cyprus Institute of Neurology and

232 Genetics. 
medRxiv preprint doi: https://doi.org/10.1101/2021.03.16.21252974; this version posted March 24, 2021. The copyright holder for this preprint (which was not certified by peer review) is the author/funder, who has granted medRxiv a license to display the preprint in perpetuity. It is made available under a CC-BY-NC-ND 4.0 International license.

\begin{tabular}{|c|c|c|c|c|c|c|c|c|c|c|c|c|c|c|c|}
\hline & Lineage & $\begin{array}{c}\text { First } \\
\text { detected }\end{array}$ & $\begin{array}{c}\text { Last } \\
\text { detected }\end{array}$ & 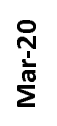 & $\begin{array}{l}\frac{1}{2} \\
\frac{1}{\alpha}\end{array}$ & 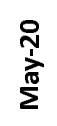 & 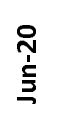 & $\frac{\stackrel{\Upsilon}{T}}{\Xi}$ & 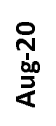 & 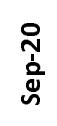 & $\begin{array}{l}\text { ำ } \\
\text { tั }\end{array}$ & $\begin{array}{l}\text { Nิ } \\
\text { วิे } \\
\text { ô }\end{array}$ & $\begin{array}{l}\text { ণิ } \\
\text { ̊ั๊ }\end{array}$ & 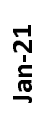 & Total \\
\hline \multirow{4}{*}{ 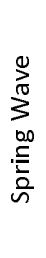 } & B.1.1.74 & $11 / 03 / 20$ & $10 / 06 / 20$ & 1 & 2 & 1 & 1 & & & & & & & & 5 \\
\hline & B.1.1.277 & $22 / 03 / 20$ & $25 / 03 / 20$ & 3 & & & & & & & & & & & 3 \\
\hline & B.1.235 & $17 / 04 / 20$ & $17 / 04 / 20$ & & 1 & & & & & & & & & & 1 \\
\hline & B.1.1.251 & $27 / 04 / 20$ & $05 / 05 / 20$ & & 1 & 1 & & & & & & & & & 2 \\
\hline \multirow{6}{*}{ 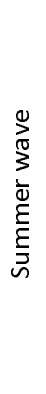 } & B.1.36 & $11 / 07 / 20$ & $11 / 07 / 20$ & & & & & 1 & & & & & & & 1 \\
\hline & B.1.236 & $17 / 07 / 20$ & $18 / 08 / 20$ & & & & & 5 & 2 & & & & & & 7 \\
\hline & B.1.2 & $05 / 08 / 20$ & $23 / 09 / 20$ & & & & & & 10 & 7 & & & & & 17 \\
\hline & B.1.1.67 & $13 / 08 / 20$ & $13 / 08 / 20$ & & & & & & 1 & & & & & & 1 \\
\hline & B.1.1.288 & $19 / 08 / 20$ & $19 / 08 / 20$ & & & & & & 1 & & & & & & 1 \\
\hline & B.1.1.192 & $27 / 08 / 20$ & $27 / 08 / 20$ & & & & & & 1 & & & & & & 1 \\
\hline \multirow{5}{*}{ 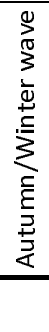 } & B.1.177 & $16 / 09 / 20$ & $26 / 01 / 21$ & & & & & & & 1 & 3 & 2 & 1 & 2 & 9 \\
\hline & B.1.258 & $23 / 09 / 20$ & $27 / 01 / 21$ & & & & & & & 7 & 16 & 12 & 25 & 13 & 73 \\
\hline & B.1.1.103 & $28 / 12 / 20$ & $29 / 12 / 20$ & & & & & & & & & & 2 & & 2 \\
\hline & B.1.1.7 & $28 / 12 / 20$ & $27 / 01 / 21$ & & & & & & & & & & 1 & 9 & 10 \\
\hline & & & & 4 & 4 & 2 & 1 & 6 & 15 & 15 & 19 & 14 & 29 & 24 & 133 \\
\hline
\end{tabular}

235 Table 1. Time course of SARS-CoV2 lineages identified in Cyprus between March 2020 and 236 January 2021. 

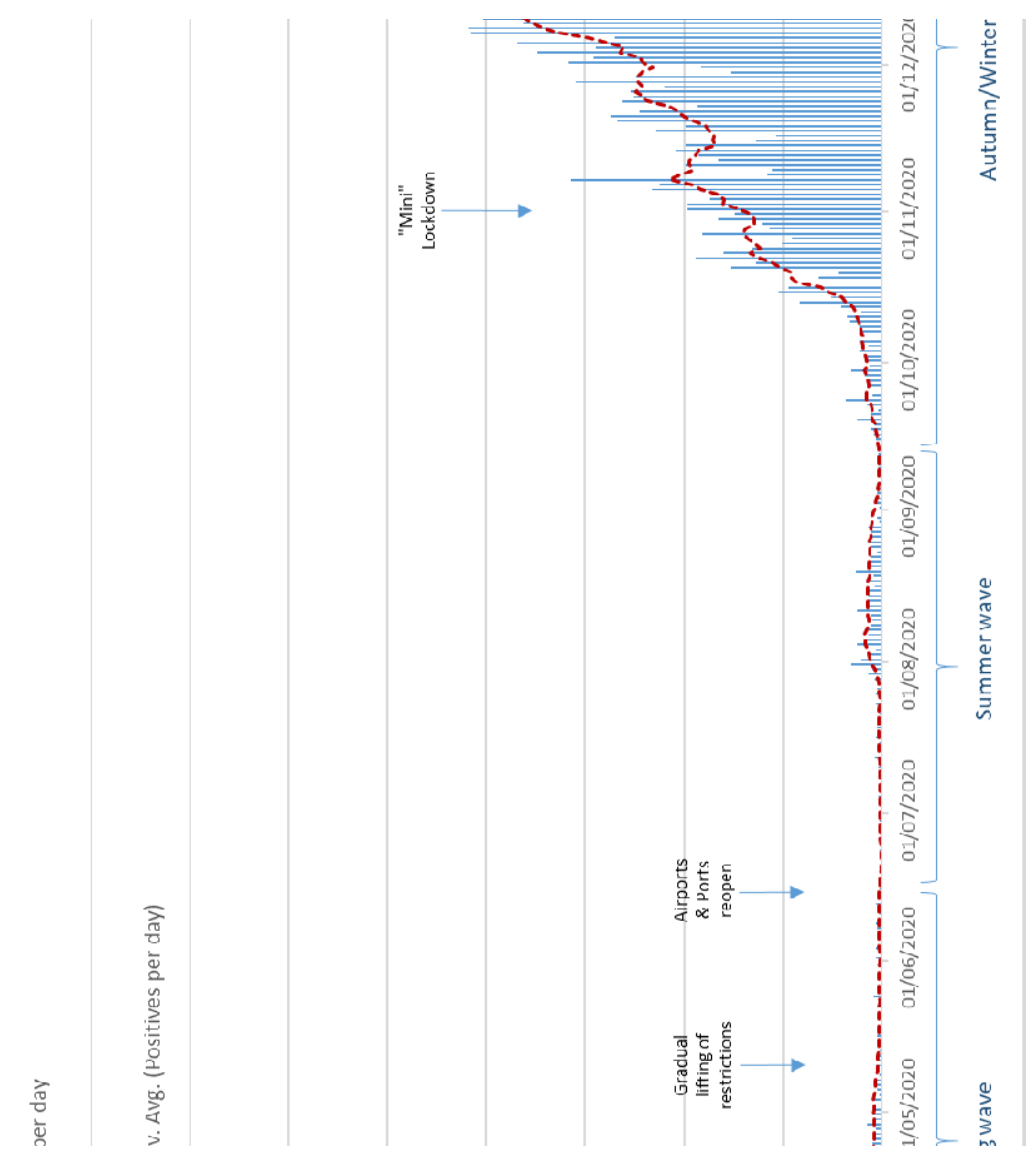

240 Fig 1. Daily number of positive SARS-CoV2 cases in Cyprus identified between March 2020

241 and January 2021 (https://covid19.ucy.ac.cy/). The start of the implementation as well as the

242 lifting of important governmental pandemic control measures are indicated. 


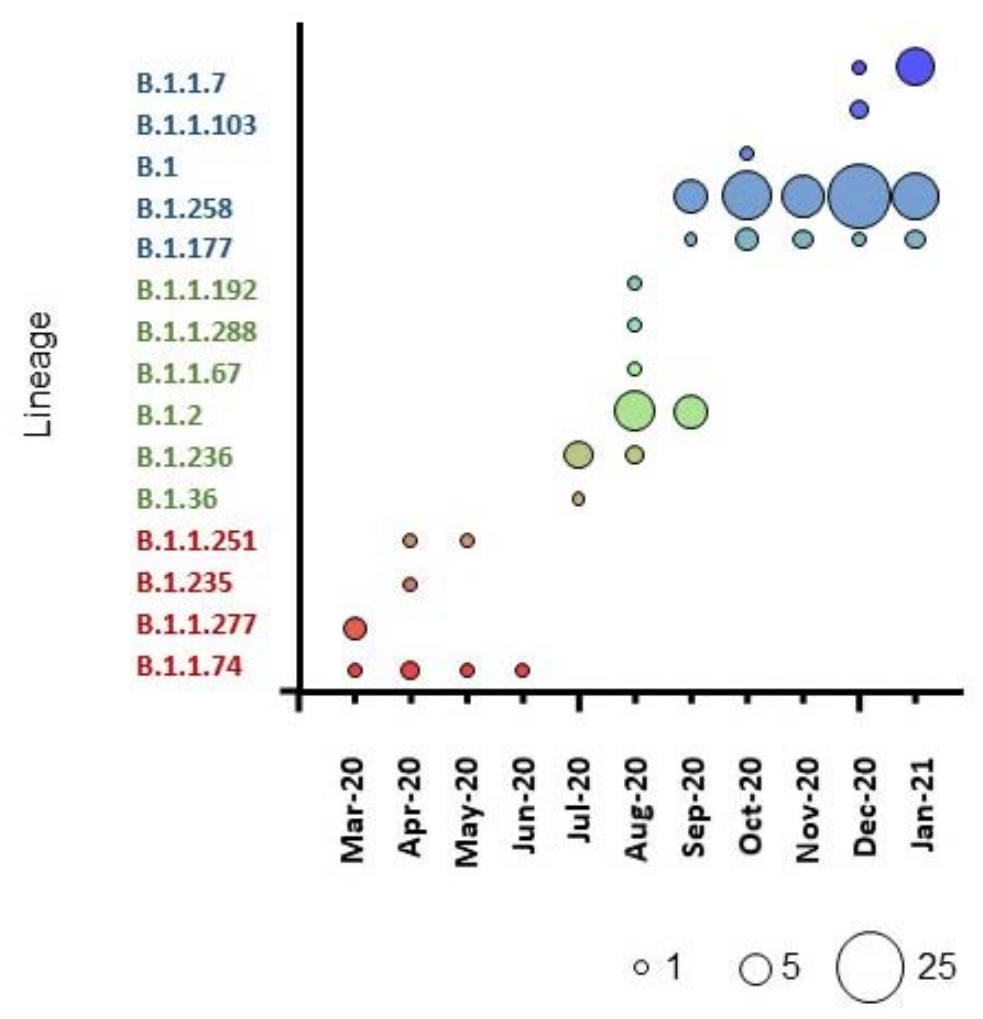

244 Fig 2. Bubble chart illustrating the pattern of SARS-CoV2 lineages identified per month. The 245 size of the circle is proportional to the number of samples. 
medRxiv preprint doi: https://doi.org/10.1101/2021.03.16.21252974; this version posted March 24, 2021. The copyright holder for this preprint (which was not certified by peer review) is the author/funder, who has granted medRxiv a license to display the preprint in perpetuity.

It is made available under a CC-BY-NC-ND 4.0 International license.
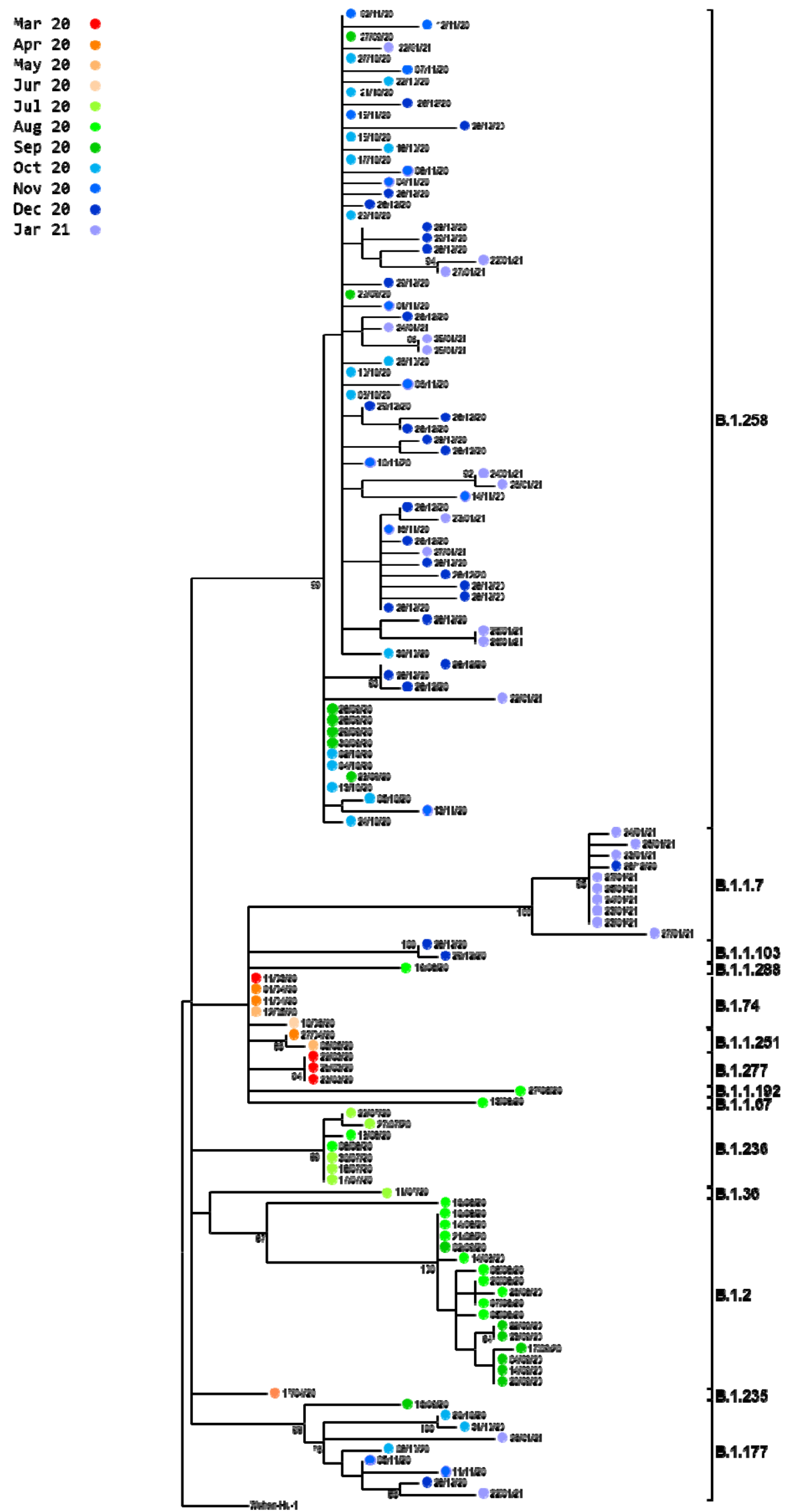
medRxiv preprint doi: https://doi.org/10.1101/2021.03.16.21252974; this version posted March 24, 2021. The copyright holder for this preprint (which was not certified by peer review) is the author/funder, who has granted medRxiv a license to display the preprint in perpetuity. It is made available under a CC-BY-NC-ND 4.0 International license.

249 Fig 3. Phylogenetic analysis of full genome sequences of 133 Cypriot strains aligned against 250 the reference genome hCoV-19/Wuhan/Hu-1/2019 (NC_045512.2). Sample names consist of 251 internal laboratory code followed by the date of sampling. The percentages of replicate trees

252 in which the associated taxa clustered together in the standard bootstrap test (1000 replicates) 253 are shown next to the branches. Only bootstrap values $>70 \%$ are shown. 
medRxiv preprint doi: https://doi.org/10.1101/2021.03.16.21252974; this version posted March 24, 2021. The copyright holder for this preprint (which was not certified by peer review) is the author/funder, who has granted medRxiv a license to display the preprint in perpetuity.

It is made available under a CC-BY-NC-ND 4.0 International license .

256

257

\section{References}

1. Gorbalenya AE, Baker SC, Baric RS, de Groot RJ, Drosten C, Gulyaeva AA, et al. The species Severe acute respiratory syndrome-related coronavirus: classifying 2019-nCoV and naming it SARS-CoV-2. Nature Microbiology. Nature Research; 2020. pp. 536544. doi:10.1038/s41564-020-0695-z

2. Wu F, Zhao S, Yu B, Chen YM, Wang W, Song ZG, et al. A new coronavirus associated with human respiratory disease in China. Nature. 2020;579: 265-269. doi:10.1038/s41586-020-2008-3

3. Zhu N, Zhang D, Wang W, Li X, Yang B, Song J, et al. A Novel Coronavirus from Patients with Pneumonia in China, 2019. N Engl J Med. 2020;382: 727-733. doi:10.1056/nejmoa2001017

4. consortiumku.muitrosnocgoc@tcatnoc TC-19 GU (COG-U. An integrated national scale SARS-CoV-2 genomic surveillance network. The Lancet Microbe. 2020;1: e99e100. doi:10.1016/s2666-5247(20)30054-9

5. Mitze T, Rode J. Early assessment of epidemiological trends associated with SARSCoV-2 variants of concern in Germany. medRxiv. 2021; 2021.02.16.21251803. doi:10.1101/2021.02.16.21251803

6. Challen R, Brooks-Pollock E, Read JM, Dyson L, Tsaneva-Atanasova K, Danon L. Risk of mortality in patients infected with SARS-CoV-2 variant of concern 202012/1: matched cohort study. BMJ. 2021;372: n579. doi:10.1136/bmj.n579

7. Quattrocchi A, Mamais I, Tsioutis C, Christaki E, Constantinou C, Koliou M, et al. Extensive Testing and Public Health Interventions for the Control of COVID-19 in the Republic of Cyprus between March and May 2020. J Clin Med. 2020;9: 3598. 
medRxiv preprint doi: https://doi.org/10.1101/2021.03.16.21252974; this version posted March 24, 2021. The copyright holder for this preprint (which was not certified by peer review) is the author/funder, who has granted medRxiv a license to display the preprint in perpetuity.

It is made available under a CC-BY-NC-ND 4.0 International license .

doi:10.3390/jcm9113598

8. Li H, Durbin R. Fast and accurate short read alignment with Burrows-Wheeler transform. Bioinformatics. 2009;25: 1754-1760. doi:10.1093/bioinformatics/btp324

9. Li H, Handsaker B, Wysoker A, Fennell T, Ruan J, Homer N, et al. The Sequence Alignment/Map format and SAMtools. Bioinformatics. 2009;25: 2078-2079. doi:10.1093/bioinformatics/btp352

10. Singer JB, Gifford RJ, Cotten M, Robertson DL. CoV-GLUE: A Web Application for Tracking SARS-CoV-2 Genomic Variation. 2020 [cited 1 Mar 2021]. doi:10.20944/preprints202006.0225.v1

11. Robinson JT, Thorvaldsdóttir H, Winckler W, Guttman M, Lander ES, Getz G, et al. Integrative genomics viewer. Nature Biotechnology. Nat Biotechnol; 2011. pp. 24-26. doi:10.1038/nbt.1754

12. Rambaut A, Holmes EC, O’Toole Á, Hill V, McCrone JT, Ruis C, et al. A dynamic nomenclature proposal for SARS-CoV-2 lineages to assist genomic epidemiology. Nat Microbiol. 2020;5: 1403-1407. doi:10.1038/s41564-020-0770-5

13. Kumar S, Stecher G, Tamura K. MEGA7: Molecular Evolutionary Genetics Analysis Version 7.0 for Bigger Datasets. Mol Biol Evol. 2016;33: 1870-1874. doi:10.1093/molbev/msw054

14. Darriba D, Taboada GL, Doallo R, Posada D. JModelTest 2: More models, new heuristics and parallel computing. Nat Methods. 2012;9: 772. doi:10.1038/nmeth.2109

15. Pater AA, Bosmeny MS, Barkau CL, Ovington KN, Chilamkurthy R, Parasrampuria M, et al. Emergence and Evolution of a Prevalent New SARS-CoV-2 Variant in the United States. bioRxiv. 2021; 2021.01.11.426287. doi:10.1101/2021.01.11.426287 
medRxiv preprint doi: https://doi.org/10.1101/2021.03.16.21252974; this version posted March 24, 2021. The copyright holder for this preprint (which was not certified by peer review) is the author/funder, who has granted medRxiv a license to display the preprint in perpetuity.

It is made available under a CC-BY-NC-ND 4.0 International license .

302

303

304

16. Guthrie JL, Teatero S, Zittermann S, Chen Y, Sullivan A, Rilkoff H, et al. Detection of the novel SARS-CoV-2 European lineage B.1.177 in Ontario, Canada. medRxiv. medRxiv; 2020. p. 2020.11.30.20241265. doi:10.1101/2020.11.30.20241265

17. Pwg M, Leon GA, Barra de E, Patrick Mallon P. Whole-genome sequencing of SARS-CoV-2 in the Republic of Ireland during waves 1 and 2 of the pandemic. medRxiv. 2021; 2021.02.09.21251402. doi:10.1101/2021.02.09.21251402

18. Hodcroft EB, Zuber M, Nadeau S, Crawford KHD, Bloom JD, Veesler D, et al. Emergence and spread of a SARS-CoV-2 variant through Europe in the summer of 2020. medRxiv. medRxiv; 2020. p. 2020.10.25.20219063. doi:10.1101/2020.10.25.20219063

19. Brejová B, Hodorová V, Boršová K, Čabanová V, Reizigová L, Paul ED, et al. B.1.258\$Delta\$, a SARS-CoV-2 variant with \$ Delta\$H69/\$Delta\$V70 in the Spike protein circulating in the Czech Republic and Slovakia. 2021 [cited 2 Mar 2021]. Available: http://arxiv.org/abs/2102.04689

20. Kemp SA, Datir RP, Collier DA, Ferreira IATM, Carabelli A, Harvey W, et al. Recurrent emergence and transmission of a SARS-CoV-2 Spike deletion $\triangle \mathrm{H} 69 / \mathrm{V} 70$. bioRxiv. bioRxiv; 2020. p. 2020.12.14.422555. doi:10.1101/2020.12.14.422555

21. Thomson EC, Rosen LE, Shepherd JG, Spreafico R, da Silva Filipe A, Wojcechowskyj JA, et al. Circulating SARS-CoV-2 spike N439K variants maintain fitness while evading antibody-mediated immunity. Cell. 2021;184. doi:10.1016/j.cell.2021.01.037

22. Preliminary genomic characterisation of an emergent SARS-CoV-2 lineage in the UK defined by a novel set of spike mutations - SARS-CoV-2 coronavirus / nCoV-2019 Genomic Epidemiology - Virological. [cited 2 Mar 2021]. Available: https://virological.org/t/preliminary-genomic-characterisation-of-an-emergent-sars- 
medRxiv preprint doi: https://doi.org/10.1101/2021.03.16.21252974; this version posted March 24, 2021. The copyright holder for this preprint (which was not certified by peer review) is the author/funder, who has granted medRxiv a license to display the preprint in perpetuity.

It is made available under a CC-BY-NC-ND 4.0 International license .

cov-2-lineage-in-the-uk-defined-by-a-novel-set-of-spike-mutations/563

23. RAPID RISK ASSESSMENT: SARS-CoV-2 increased circulation of variants of concern and vaccine rollout in the EU/EEA, 14th update. [cited 2 Mar 2021]. Available: https://www.ecdc.europa.eu/sites/default/files/documents/RRA-covid-1914th-update-15-feb-2021.pdf

24. Hadfield J, Megill C, Bell SM, Huddleston J, Potter B, Callender C, et al. NextStrain: Real-time tracking of pathogen evolution. Bioinformatics. 2018;34: 4121-4123. doi:10.1093/bioinformatics/bty407

25. Tegally H, Wilkinson E, Giovanetti M, Iranzadeh A, Fonseca V, Giandhari J, et al. Emergence and rapid spread of a new severe acute respiratory syndrome-related coronavirus 2 (SARS-CoV-2) lineage with multiple spike mutations in South Africa. medRxiv. medRxiv; 2020. p. 2020.12.21.20248640.

doi:10.1101/2020.12.21.20248640

26. Genomic characterisation of an emergent SARS-CoV-2 lineage in Manaus: preliminary findings - SARS-CoV-2 coronavirus / nCoV-2019 Genomic Epidemiology - Virological. [cited 4 Mar 2021]. Available: https://virological.org/t/genomiccharacterisation-of-an-emergent-sars-cov-2-lineage-in-manaus-preliminaryfindings/586

27. Jangra S, Ye C, Rathnasinghe R, Stadlbauer D, Krammer F, Simon V, et al. The E484K mutation in the SARS-CoV-2 spike protein reduces but does not abolish neutralizing activity of human convalescent and post-vaccination sera. medRxiv Prepr Serv Heal Sci. 2021 [cited 4 Mar 2021]. doi:10.1101/2021.01.26.21250543

28. Liu Z, VanBlargan LA, Rothlauf PW, Bloyet LM, Chen RE, Stumpf S, et al. Landscape analysis of escape variants identifies SARS-CoV-2 spike mutations that 
medRxiv preprint doi: https://doi.org/10.1101/2021.03.16.21252974; this version posted March 24, 2021. The copyright holder for this preprint (which was not certified by peer review) is the author/funder, who has granted medRxiv a license to display the preprint in perpetuity. It is made available under a CC-BY-NC-ND 4.0 International license. attenuate monoclonal and serum antibody neutralization. bioRxiv. bioRxiv; 2020. doi:10.1101/2020.11.06.372037

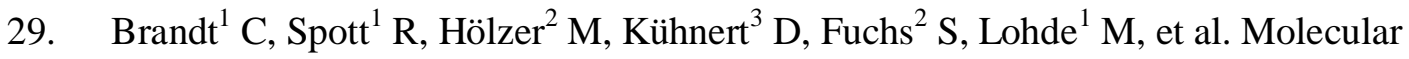
epidemiology of SARS-CoV-2 - a regional to global perspective. medRxiv. 2021; 